\title{
FAZENDO PESSOAS, FAZENDO COLETIVOS: AS MULHERES XIKRIN DO BACAJÁ
}

\author{
Clarice Cohn $\square$
}

Universidade Federal de São Carlos I São Carlos - SP - Brasil 


\section{RESUMO}

Este artigo busca demonstrar como as mulheres xikrin (as menire) participam ativamente na produção de pessoas e coletivos, mostrando, ainda, a partir de várias novas atuações e iniciativas que elas têm tomado, o quanto têm potencializado o feminino em tempos de crise e desafios, tendo em vista sua participação na produção de pessoas, coletivos e de seu kukradjà, conceito debatido na análise. O texto, fruto de quase 30 anos de convívio e estudo, argumenta que, se as mulheres sempre tiveram uma parte importante nesse processo, elas a têm potencializado nos últimos anos, enfrentando os desafios e estando na luta.

Palavras-chave: Mebengokré; Xikrin do Bacajá; gênero; mulheres indígenas; megaempreendimentos; direitos indígenas.

\section{MAKING PEOPLE, MAKING COLLECTIVES: XIKRIN WOMEN FROM BACAJÁ}

ABSTRACT

This article aims to demonstrate how the xikrin women (menire) actively participate in the production of people and collectives, showing, from various new actions and initiatives that they have taken, how much they have empowered the feminine in times of crisis and challenges, considering their participation in the production of people, collectives and their kukradjà, a concept debated in the analysis. This article, resulting from nearly 30 years of conviviality and study, argues that if women have always had an important part in this process, they have empowered it in recent years, facing challenges and struggle.

\section{Keywords: Mebengokré; Xikrin of Bacajá;}

gender; indigenous women;

\section{CREANDO PERSONAS, CREANDO COLECTIVOS: LAS MUJERES XIKRIN DEL BACAJÁ}

\section{RESUMEN}

Este artículo busca demostrar cómo las mujeres Xikrin (menire) participan en la producción de personas y colectivos, mostrando cómo ellas han potencializado lo femenino en tiempos de crisis y desafíos a partir de nuevas actuaciones e iniciativas, y teniendo en consideración su participación en la creación de personas, colectivos y de su kukradjá, concepto debatido en el análisis. El texto, fruto de casi 30 años de convivencia y estudio, argumenta que, si las mujeres siempre tuvieron una parte importante en este proceso, en los últimos años se ha potencializado su actuar, en medio de la superación de desafíos y en la lucha.

Palabras clave: Mebengokré; Xikrin del Bacajá; género; mujeres indígenas; mega emprendimientos; derechos indígenas. 


\section{INTRODUÇÃO}

A questão das mulheres entre os Xikrin (que são Mebengokré, como os demais Kayapóp ${ }^{1}$ ) tem sido alvo de controvérsias na antropologia há décadas. Se monografias sobre os Mebengokré foram escritas, desde Dreyfus (1963), Turner (1966) ou, para os Xikrin especificamente, Vidal (1977), o primeiro modelo analítico sobre eles surge com a proposta elaborada por Turner (1979a). Este é apresentado no âmbito das pesquisas etnográficas realizadas pela equipe Harvard Central Brazil Project (HCBP), que visou construir um modelo analítico capaz de compreender os Jê do Brasil Central, no que denominaram "comparação controlada”, a partir da percepção de que aqueles até então existentes, em especial os africanistas do estrutural-funcionalismo britânico, não permitiam a compreensão antropológica desses povos, e distribuiu pesquisadores brasileiros e estadunidenses, ligados a essa universidade e ao Museu Nacional da Universidade Federal do Rio de Janeiro, entre povos Jê Setentrionais e Centrais. Porém, como demonstrei em outro texto (Cohn no prelo), essa análise da sociedade Mebengokré acaba por isolar tanto a proposta analítica da partilhada e utilizada pelos demais pesquisadores, quanto à análise sobre os Kayapó - e, portanto, estes - do conjunto da coletânea, e que foi referência a muitas das produções etnológicas que a esta produção se seguiram. Na coletânea Dialectical Societies (Maybury-Lewis [org] 1979), os textos de Turner (1979a, 1979b) aparecem, reveladoramente, no centro do livro - isso porque ele apresenta dois textos, um que elabora sua proposta interpretativa, outro que a utiliza para analisar os Kayapó -, e seu trabalho acaba por ficar sem diálogo com os demais, que partilham do modelo proposto na introdução e na conclusão. Posteriormente, a proposta apresentada por Turner (1979a, 1979b) nesta ocasião foi definida por Eduardo Viveiros de Castro (2002:333-334), ao lado da de Riviere (1984), como "economia política do controle", ambos referindo-se, o primeiro para o Brasil Central e o segundo para as Guianas, ao controle do genro pelo sogro, e ao poder e à produção nesses contextos.

É fato que o HCBP demonstrou ter problemas no que se refere à participação das mulheres nas muitas aldeias em que trabalharam e na etnografia dos diversos povos, não limitadas, portanto, à referida proposta de Turner². Porém, esta era a mais

1 No texto, aparecerá essas várias denominações, segundo os/as autores/as utilizam; quando falo dos Xikrin, estou falando dos Xikrin do Bacajá, que há décadas se separaram dos Xikrin do Cateté. Uso também Xikrin ou Mebengokré, que, para além de uma autodenominação ou um etnônimo pelo qual os Xikrin se referem a si mesmos, indica um modo de ser e estar no mundo, como desenvolvo em Cohn (2005).

2 Logo que essa proposta foi lançada, diversas outras etnografias foram feitas, de modo a trazer as mulheres jê para o centro do debate, com destaque para a análise da vida doméstica, feita por Caiuby Novaes (1986); a revisão da nominação 
certamente centrada nas relações estabelecidas entre homens, com uma inflexão de idade. No modelo por ele proposto, sogros controlam seus genros, e os mais velhos exercem controle sobre os mais novos. Isto daria a dinâmica de produção e de poder entre os Kayapó, assim como explicaria, sugere, o parentesco.

Turner (1979b) aborda a sociedade Kayapó pelo ponto de vista dos homens e da atividade política, e propõe que ela seja entendida a partir da submissão, no âmbito coletivo, dos mais novos aos mais velhos, $\mathrm{e}$ no âmbito doméstico, do genro ao sogro (possibilitada pela regra de residência uxorilocal, que seria um meio para o controle do genro). Utilizando uma análise do desenvolvimento do grupo doméstico (Fortes 2011[1958]), ele argumenta pela passagem da submissão quando da inserção do genro à casa para a aquisição da autoridade, quando este se torna membro do casal mais velho e passa a ter genros. No âmbito coletivo, que sugere se relacionar de modo complexo com o doméstico na reprodução da sociedade, embora sejam as "sociedades masculinas" que o constituem as que atuariam na política aldeã, ele enfatiza que é com base na relação sogro/genro que se faz a divisão da sociedade nos períodos de nomadismo da estação seca ${ }^{3}$.

Esses primeiros trabalhos estavam, no entanto, marcados por outra questão relativa a gênero: a dificuldade em dar conta da sexualidade e de várias situações vividas pelas mulheres, tomadas a partir de um olhar masculino e moralista. Como aponta Lea (2005), foi assim que a literatura tendeu a de remeter às me kupry, mulheres que, por razões variadas, não são casadas. Entre as mulheres xikrin do Bacajá, estas são as mães solteiras - fato que pode ser melhor avaliado por ser exatamente a $\mathrm{m} /$ paternidade o que, de fato, realiza o casamento (Cohn 2000) -, seja por terem tido filhos com homens com quem se relacionam mas já constituíram família, seja por terem se separado de um casamento anterior, seja por outras razões, tais como escolhas pessoais, e várias delas constituíram, nessas três décadas em que convivemos, novas famílias. Certamente, trata-se de uma situação difícil, já que uma mulher que cria filhos fora do casamento não conta com um esposo caçador e pescador, embora outras

feminina entre os Akwẽ-Xavante, feita por Lopes da Silva (1986); a análise das pinturas corporais realizadas pelas mulheres, de autoria de Vidal (1992), entre os Xikrin do Cateté; além dos importantes estudos de Vanessa Lea (1986, 1993, 1994, 1995, 1999, 2012), que analisaremos com mais vagar neste artigo, abrindo caminho para novas elaborações que se seguiram nas décadas decorrentes.

3 A análise de Bamberger (1979), também sobre os Kayapó-Gorotire, enfoca as formas de participação nas atividades políticas, revelando a relação das diferenças nessa participação, com as categorias masculinas de idade, e o faccionalismo. Nesse sentido, sua análise fica bastante circunscrita aos Kayapó; mas merece ser considerada com mais atenção do que tem sido, e em diálogo com o "modelo jê", proposto pelo HCBP, já que enfatiza a importância das categorias de idade e sua natureza gradativa, o que é pouco explorado em Turner (1979a, 1979b), o qual apenas afirma a hierarquia baseada na senioridade. 
pessoas possam assumir essa tarefa, seja na casa dela, seja na relação aben pa amy, que envolve dois casais que podem manter relações sexuais e compartilham alimentos, de modo, inclusive, a chamar todas as crianças geradas enquanto durou essa relação de filhos, kra (Cohn 2000). Mas o moralismo da etnografia vigente definia essa condição - marcada, certamente, por uma grande liberdade sexual - como prostituição, ou mulheres que seriam desfrutáveis por todos, negando-lhes, claramente, a legitimidade das várias razões que as levaram a assumir criar filhos sem um cônjuge. O mesmo vale para as relações sexuais que aconteciam em certas etapas de alguns rituais e não acontecem mais, sustentam as Xikrin, para quem, com os kuben, vieram também os ciúmes e a sovina de maridos -, como "estupro coletivo", negando mesmo o aspecto ritual dessa prática (ou seja, não só negando a possibilidade de as mulheres falarem sobre isso, mas a própria ênfase antropológica, clássica, no ritual e nas razões estritamente rituais para algumas práticas).

Assim, o dualismo, em seus aspectos de produção de pessoas e dos domínios masculino e feminino, torna-se, no modelo de Turner, hierarquizado, em uma assimetria etária e de gênero. Para ele, a sociedade kayapó tem seu fundamento não na produção material, mas na de pessoas, que é levada a cabo no âmbito doméstico e estabelece a dominância masculina porque os homens, estando ligados às relações interfamiliares e comunitárias - as quais, por requererem (termo enfatizado pelo autor) maior complexidade do que as atividades de substância - as definem e organizam. Neste modelo, as relações de nominação, aquelas que constituem os grupos cerimoniais, também são tratadas como subordinadas à lógica de formação familiar, a qual se dirige, ao longo do ciclo de vida dos indivíduos, à autoridade masculina nas relações interfamiliares, e à feminina daquelas intrafamiliares. Uma ideia de socialização primária, feminina, feita nas casas, e secundária, masculina, completa a assimetrização das relações de gênero; por ela, o domínio das mulheres sobre os seus filhos homens acabaria na socialização primária, até quando os meninos são direcionados para a "Casa dos Homens" (o $n g a ̀ b)$, onde são criados entre homens; enquanto as meninas, permanecendo em casa, são sempre criadas pelas mulheres: caberia a estas, portanto, a socialização secundária apenas de suas filhas. Essa entrega dos filhos pelas mães para o domínio masculino seria, dada a uxorilocalidade, a passagem da casa natal à casa onde se entra como genro para se tornar sogro um dia, fazendo o grupo doméstico já aludido ser inserido no modelo.

Vanessa Lea, centrando seu trabalho exatamente nas relações de nominação, inverte essa perspectiva. Voltando o olhar ao que é percebido 
como periferia (e periférico), demonstra que são as Casas (conceito retirado de Lévi-Strauss) as detentoras de nomes e bens simbólicos, a seu ver os únicos bens escassos na sociedade Kayapó, as quais definem a posição social do indivíduo. Assim, para essa autora, em contraste com Turner, o que se manifesta no pátio deve ser entendido a partir das Casas, que se mostram como o nível relevante para a análise dessa sociedade (Lea 1986, 2012). Em outro trabalho, essa autora sugere que a hierarquia entre os domínios masculino e feminino não deve ser tomada como uma via de mão única, e sim, a partir de uma inspiração dumontiana, como em um jogo em que um engloba o outro em dada situação, e é englobado em outra (Lea 1995). Assim, o trabalho de Lea, com uma rica etnografia sobre os nomes pessoais e os nekretch, coisas possuídas pelas pessoas ${ }^{4}$, e sua transmissão e circulação, recusa duplamente a hierarquização de gênero proposta por Turner - a invertendo, subjugando o centro à periferia, o pátio onde ocorrem os rituais e os eventos públicos às Casas, que têm e mantêm tudo o que permite a realização desses eventos, e negando mesmo a hierarquia de mão única, a submetendo ao jogo de englobamento.

As relações de gênero foram retomadas por outro etnógrafo dos Mebengokré, enfocando agora exatamente os Xikrin do Bacajá, com quem trabalhamos neste texto. Bill Fisher (1991), analisando as relações sociais e políticas pela produção e distribuição de alimentos por pessoas e famílias, retoma a questão de gênero em sua relevância na delimitação dessas produções, mas vai além, ao demonstrar a organização de cada gênero, em separado, no que se refere à produção e a outras decisões relevantes a cada um deles. Propõe, então, que se atente para o que denomina de "associações femininas" e "associações masculinas", e demonstra que, embora estejam ligadas - dado que as últimas se centram nos chefes da aldeia e as primeiras, na esposa dos chefes -, revelam uma esfera de tomada de decisões e de colaboração autônoma e clivada pelo gênero.

Novos trabalhos permitem rever mais de perto a participação das mulheres entre os Xikrin, e serão retomados ao longo do texto. Mas esta introdução nos permite entender o problema que se coloca para a antropologia referente ao olhar sobre as mulheres xikrin, e como as análises têm se pautado, até a virada do século, de um modo ou de outro, na cisão de gêneros. Pretendo, aqui, demonstrar a participação das mulheres nas várias dimensões da vida xikrin, ao colaborar com o que mais lhes importa - fazer pessoas belas e fortes, produzir

4 Os Xikrin do Bacajá utilizam-se do termo kukradjà para abarcar, entre outras coisas, esse mesmo sentido; isso será retomado ao longo do texto. 
alegria para todos, fazer coletivos, estes também marcados pela beleza, pela força e pela alegria -, e que elas o têm feito abraçando o embate, a política tal como realizada pelos não indígenas (kuben), experimentando novas formas de produção, geração de renda e associativismo, colocando-se como as mantenedoras da Terra Indígena, ou seja, potencializando o feminino neste momento de crise, com as construções de megaempreendimentos e a violação de seus direitos.

\section{FAZENDO CORPOS, FAZENDO PESSOAS: DA BELEZA E DA ALEGRIA}

A formação de corpos e a constituição dual das pessoas é outro tema clássico na bibliografia jê (Da Matta 1976; Melatti 1976; Maybury-Lewis 1979). Pessoas são, argumentam, a conjugação de corpos e nomes, e cada parcela sua gera relações diferentes, a dos nominadores e a dos genitores, de modo que “quem dá corpo não dá nome” (Melatti 1976), e vice-versa. Esse jogo, no nosso modelo jê, estaria bipartite também pelas relações de gênero, já que nomes pessoais são masculinos ou femininos, e sua transmissão se dá pelos gêneros correspondentes (Vidal 1977; Lea 1986, 1999, 2012). Do mesmo modo, na bibliografia jê, a formação do corpo durante a gestação sempre foi clivada pelo gênero, dando ênfase na participação masculina: seria o sêmen que formaria o corpo, em uma formação gradativa, que envolve muito aporte de sêmen no útero (o lugar da criança, $k r a$ djà), em repetidas relações sexuais com homens diversos, que depois deveriam assumir a paternidade compartilhada (Vidal 1977; Cohn 2000). Ainda nos temas já tornados clássicos, a "comunidade de substância", expressão cunhada por Da Matta (1976) para os Apinajé, une genitores e filhos; se esta relação é especialmente visível durante os primeiros anos da vida da criança, é duradoura e vitalícia (Cohn 2000), de modo que um corpo extendido tenha que cuidar de fazer os resguardos (alimentares ou outros, como a caça) sempre que alguém com que se compartilhe substância esteja em situação de vulnerabilidade, como, no caso exemplar, doente.

Mas, como se vê, se a bibliografia clássica nos dá muitos aportes e elementos para entender aspectos da organização social (a preocupação primeira dos pesquisadores do HCBP), da nominação, da formação de pessoas, sendo que pouco se fala sobre as mulheres nesse processo, a não ser genericamente, e elas são excluídas da cena - literalmente as relegando para a periferia -, como o demonstramos no modelo de Turner. Foi Lea $(1988,1992,1995,1999,2012)$ quem ressaltou a importância das mulheres, em um aspecto crucial, a nominação e a transmissão das prerrogativas nektrets, procedimentos que andam juntos, já que respondem à mesma lógica de transmissão e 
circulação. É fundamental reter aqui seu argumento de que, se nomes e prerrogativas masculinos são transmitidos entre homens, todos os nomes e as prerrogativas seriam do domínio das Casas - uma categoria que ela assinala ultrapassar as casas físicas, e que pode envolver um conjunto desses espaços, repetindo-se em diferentes aldeias a partir de um esquema ideal de distribuição (Lea 1995). Assim, não seria suficiente olhar para o domínio masculino - o centro, o pátio, imagem que vem da espacialidade das aldeias jê e reverbera na antropologia como central/periférico por muito tempo -, onde ocorrem os rituais, para entender os papéis que lá estão em jogo, já que tudo que adorna as pessoas neste momento estava guardado pelas Casas, pelas mulheres, que, de algum modo, deteriam, ou controlariam, sua distribuição.

Seja como for, estamos ainda longe de ver como as mulheres produzem essas novas pessoas. Ainda nos falta um olhar ao dia a dia, aos afazeres diários e entre parentes, e à participação feminina na preparação e na garantia da força e da alegria de cada ritual ${ }^{5}$. Embora essa proposta possa parecer manter a clivagem público/privado, centro/ periferia, com um olhar para o cotidiano, pretendo, ao contrário, mostrar como as mulheres são ativas em todos os domínios classicamente recortados - e por gênero - entre os jê, de modo a demonstrar que a produção da pessoa - mesmo se retivermos o dualismo corpo/nome - só é possível, em qualquer domínio, com a participação ativa das mulheres.

Comecemos pela alimentação. Afinal, se há ainda aqui uma diferença no aporte alimentar de mulheres (que fazem roças e sua colheita, e parte da coleta de produtos da mata) e de homens (que caçam, pescam e fazem outra parte da coleta na mata), isso não deve significar um papel menor por parte das mulheres, muito pelo contrário ${ }^{6}$.

Cabe às mulheres a alimentação de todos durante a maior parte do dia, até que a caça, ou a pesca, se realizem, nas matas e rios, e as carnes e os peixes cheguem na aldeia. Assim, o dia costuma ${ }^{7}$ começar com o consumo da macaxeira, que é mantida (cortada e em cestas) na água desde o

5 Foi Fisher (2003) quem primeiro chamou a atenção para esse aspecto fundamental do fazer ritual entre os Xikrin do Bacajá, o de se fazer alegre. Posteriormente, em nossas etnografias, Gordon (2005), para os Xikrin do Cateté, e eu (Cohn 2005), para os Xikrin do Bacajá, retomamos este tema. Recentemente, Monteiro (2019) mostrou a importância da alegria para os Krahô, o que nos permite pensá-lo como um dos temas jê deixado de lado pelos modelos clássicos, mas que são de grande importância para esses povos.

6 Aqui, lembremos outro vício clássico da bibliografia antropológica: o da ênfase na caça e na proteína animal nos aportes alimentares entre indígenas. Esta tese há muito já foi debatida e refutada (cf., por exemplo, Beckerman 1994).

$7 \mathrm{Ou}$ costumava começar assim. Falaremos adiante um pouco acerca do consumo dos produtos industrializados e de inovações alimentares precedidas na história recente pela farinha de mandioca, que só começou a ser produzida e consumida há poucas décadas. 
último banho do dia anterior, recolhida ao primeiro banho da manhã e distribuída para todos, inclusive para os caçadores ou pescadores, que a levarão para se alimentarem em suas excursões, nesse modo de preparo ou como farinha. As mulheres, então, após deliberarem coletivamente, vão às roças ou à coleta, esta individual ou coletiva. Se elas vão às roças, vão em grupos de irmãs, só elas ou com as suas mães ${ }^{8}$ - as quais costumam fazer as roças próximas umas das outras (Vidal 1977; Fisher 1991; Cohn 2005) -, e retornam juntas, cada qual com seu paneiro de produtos da roça e com lenha. Chegando em casa, vão para os fundos, o lugar do forno de pedra ( $k i)$, e preparam um único fogo em que, porém, cada qual organiza seus produtos em separado, para serem consumidos separadamente com filhos e cônjuges (Fisher 1991).

Assar os tubérculos leva horas, dedicadas pelas mulheres a cuidarem dos filhos e de outros afazeres, até abrirem o forno e separarem seus alimentos, parte dos quais é guardada para seus maridos, a outra parte é levada imediatamente para o rio, para que seja consumida, pelas mulheres, meio imersas na água, com os filhos, separadas em grupos. Este é considerado um dos mais gostosos e divertidos momentos do dia - grupos de mulheres e crianças consumindo a batata doce, ainda quente, entre grandes goles de água, comparando a qualidade das batatas entre si, comentando seu sabor, vendo as crianças nadarem e brincarem, cuidando para que não se esqueçam de também comer ${ }^{9}$.

Há ocasiões, entretanto, em que elas não vão à roça: vão, em grupos maiores ou menores, coletar frutos, como castanha-do-pará, ingá, babaçu, em lugares previamente combinados nas reuniões das associações de mulheres, como cunhou Fisher (1991) e a que já aludimos anteriormente. Igualmente, o dia será passado consumindo esses frutos, em frente às casas, em rodas que reúnem mulheres e crianças, discutindo quais os melhores lugares para a coleta naquela estação, qual a situação de tal castanheira ou açaizal, se os frutos já estão maduros ou se estão verdes, discutindo as fortunas diversas relativas à coleta ${ }^{10}$. Esses frutos - a maior parte deles não necessitando de processamento para o consumo, a não ser a bacaba e o açaí - também têm uma parte separada para os homens, quando chegarem, e são também circulados entre os diversos parentes.

8 Algumas crianças acompanham suas mães e avós à roça, mas é comum planejar esse arranjo referente a quem vai a cada dia à roça, com o intuito de permitir a permanência de alguma das na aldeia para cuidar das crianças que, por razões várias, não forem à roça.

9 Para a variedade nas roças, cf. Fisher (1991) e Cohn $(2005,2011)$.

10 Para a coleta, o uso e a movimentação na floresta, ver Tseouliko (2018a). Em Tseouliko (2018b), discute-se mais especificamente como as mulheres (também) marcam árvores de diversos frutos, como as castanheiras, bem como locais de coleta de babaçu na mata. 
Se alguns dos homens permanecem na aldeia e não vão para o mato, ficam mais frequentemente no $n g a ̀ b$, e lá recebem seu quinhão de comida da colheita, da coleta ou um prato de alimento cozido -, dado por suas esposas, mães e irmãs, e levado pelas crianças. Assim também acontecia quando os meninos dormiam e passavam os dias, em um período anterior ao casamento, na Casa dos Homens ${ }^{11}$, pois as mulheres nunca deixaram de mandar, por meio das crianças, alimentos para eles. Esses homens também visitam suas irmãs quando recebem algo para comer, relação que, como busquei demonstrar, vão construindo desde cedo, ainda crianças (Cohn 2000b).

Apenas quando os caçadores e pescadores vão chegando - eles também podem ter ido sozinhos ou em grupos - ocorre o preparo por parte dos homens mais velhos daquilo que é trazido, os quais contam com o apoio de mulheres mais velhas que já tenham passado pela menopausa; após isso, há a divisão desses insumos entre as casas para o processamento. Essa distribuição da caça ou da pesca cabe às mulheres, e é realizada pelas crianças, que vão levar pedaços de carne de caça ou de peixes, embrulhados em folhas ou espetados em pauzinhos, para que não toquem no sangue. Os pedaços que couberam, então, a cada casa são preparados, em novo fogo, no forno de pedra ki, para serem consumidos, podendo ficar uma parcela - o couro da anta, com sua gordura, peixes moqueando, eventualmente pedaços de carnes salgados - para a manhã seguinte. Assim, chegamos ao fim do dia, e é com essa alimentação - que é toda feita até saciar, ficar arine - que homens e mulheres se reúnem, eles no ngàb, elas em frente às casas, deitadas em esteiras e em grupos, com as crianças circulando por todos esses espaços, até a hora de dormir.

Entretanto, e cada vez mais, os alimentos consumidos não vêm apenas das roças, da mata e dos rios, mas também das vilas e cidades, tendo em vista a entrada de recursos financeiros com programas de governo, como o Bolsa Família ou o Salário Maternidade, bem como com os cargos ligados à escola e referentes à função de Agente Indígena de Saúde (AIS) e de Saneamento (AISAN), com as participações como bolsistas em projetos e com o aporte de alimentos, direta ou indiretamente, em nome de mitigação de impactos decorrentes da construção da Usina Hidrelétrica (UHE) de Belo Monte - seja pela circulação mais intensa de lideranças nas cidades para reuniões e oficinas de formação, seja pela circulação contrária, de equipes atuando nos programas de mitigação e compensação de impactos pelas aldeias.

11 Entre os Xikrin, até o contato e a pacificação, e a decorrente sedentarização em aldeias maiores (Cohn 2005), o ngàb não existia, e esse espaço de encontro ficava fora do centro da aldeia, sendo chamado de atuk (Vidal 1977; Gordon 2005). 
Assim, panelas de arroz e feijão cozidos podem ser encontradas em praticamente todas as casas, com alimentos servidos às crianças, quando elas passam em casa com fome, ou a visitas, como as dos irmãos, ou mandados em forma de pratos feitos aos homens - cônjuges, irmãos, filhos -, reunidos no ngàb. Às vezes, há acesso a carne de gado e a frango, usados como "misturas" acompanhando o arroz e o feijão. Macarrão e corante, além de óleo e sal, são itens também cada vez mais indispensáveis. Café, açúcar, leite em pó, bolachas são itens constantes (e de demanda constante), sendo estas últimas remetidas às crianças. Reuniões têm sido sempre realizadas com uma garrafa grande de café para os homens, e as mulheres também mandam

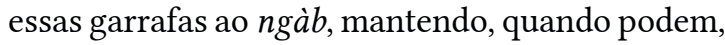
uma garrafa cheia de café pronto em casa para oferecer às visitas.

Estes alimentos, ao contrário dos que vêm das roças, da mata e dos rios, assados ou consumidos crus, como frutos, são todos cozidos. Isso levou, desde sempre, a uma preocupação sobre a condição do corpo formado com essa ingestão, não só porque era comida de não indígena (kuben), mas principalmente pela sua cocção. Alimentos assados fazem corpos fortes, tôx. Ao contrário, alimentos cozidos formam um corpo enfraquecido (rerekre, em analogia ao fato dos alimentos ficarem também amolecidos no processamento), o que se deve evitar ou mesmo se deve temer. Em um discurso voltado às crianças, o chefe Bep-tok, conhecido por Onça, já enfatizava, na década de 1990, o risco de comerem muito alimento cozido e não crescerem fortes, tôx (Cohn 2006). No entanto, esses alimentos enfraquecidos, amolecidos, quando ainda eram consumidos em menor quantidade, foram, até um dado momento, reconhecidos como bons substitutos da gradação de perigo e potência que se deve respeitar em resguardos - vegetais, alguns peixes, peixes de couro, algumas carnes, até chegarem a consumir as carnes consideradas fortes, porque gordurosas, porcões e antas. Estes alimentos com maior potência, em especial a caça, devem ser consumidos apenas após terem sido administrados remédios específicos do mato (bà kam pidjô), que alguns conhecedores sabem, e que neutraliza o perigo de sua ingestão. Mas o consumo mais frequente desses alimentos foi demonstrando seu perigo e sua potência, e Bekatenti, o Maradona, grande conhecedor de remédios do mato, me contou recentemente ter descoberto o remédio para a carne de gado, permitindo, assim, seu consumo com maior segurança ${ }^{12}$.

Voltando à alimentação propiciada pelas

12 Noto que, quando da realização dos Estudos Complementares do Rio Bacajá, no processo de licenciamento da UHE Belo Monte, a equipe responsável pela avaliação de "consumo alimentar" chegou a concluir, em um primeiro de quatro relatórios, a ocorrência de subnutrição entre os Xikrin do Bacajá. Surpresa com o resultado quando apresentado 
mulheres, é possível afirmar que ela não é importante apenas no dia a dia, sendo crucial para a boa realização dos rituais. Se um ritual é tão mais bem-sucedido quanto mais as pessoas dançarem, cantarem forte e ficarem alegres, parte importante dessa força e dessa alegria vem da oferta generosa de alimentos.

Em um dos rituais mais frequentemente realizados atualmente, nas aldeias da Terra Indígena TrincheiraBacajá, o mereremei, um ritual de nominação, os pais das crianças homenageadas devem ser os doadores do alimento, e não participam do ritual nas danças e nos cantos, nem consomem os alimentos preparados para a oferta; sua participação se faz o assistindo e preparando a alimentação a ser fornecida em momentos específicos durante o ritual ${ }^{13}$. Pais e mães de crianças homenageadas neste momento são chamados de krareremei - sendo kra, filho/a e, desde que anunciam seu desejo de oferecer essa festa em benefício de sua criança, articulam com seus irmãos (os irmãos do pai e as irmãs da mãe, que chamam também a criança de filho/a) o preparo do ritual - conseguir todo o material para o adorno das crianças, confeccioná-los, assim como obter os alimentos a serem ofertados na festa. Enquanto a grande caçada ritual acontece, e os homens estão em expedição pelo mato para trazer grandes quantidades de jaboti (a serem servidos assados) e, de preferência, de antas (a serem servidas em um bolo de carne assado), as mulheres preparam a massa de mandioca que vai preencher a cavidade dos jabotis assados, os quais são o principal ingrediente, ao lado da carne e do bolo de carne preparado para os/as dançarinos/ as (quando as crianças são meninas, as mulheres é quem dançam; quando são meninos, são os homens). Além de idas coletivas às roças das mães das crianças homenageadas, para fazer a colheita de uma grande quantidade de mandioca, recolhem folhas de bananeira, essenciais para cobrir o bolo (tanto para assar quanto para servir), quantidades enormes de

em reunião, para a qual fui convidada como antropóloga especialista, busquei entendê-lo melhor. O resultado disso foi a mudança de metodologia de pesquisa: acostumados a pesquisar entre ribeirinhos, as equipes faziam uma ronda pelas casas para ver seu consumo em horários que seriam de refeições - café da manhã, almoço, jantar -, sem atentar para os horários dispersos do consumo alimentar e a circulação de comidas cruas ou preparadas pelas casas e por pessoas, o que só os podia levar à conclusão de que os Xikrin não se alimentavam bem. O estudo persiste tendo numerosos problemas - como o fato de ter sido feito em apenas um ciclo hidrológico -, mas ao menos alguns deles, como esse, puderam ser revistos no processo.

13 Sobre o mereremei, ver Vidal (1977) e Cohn (2000a). Sobre a nominação e o fato de que alguns dos que recebem nome poderem ser homenageados, ou terem seu nome confirmado em um ritual, quando (e apenas quando) recebem um nome que foi ele mesmo, o nome transmitido, confirmado em ritual, ver Lea (1986, 2005) e Cohn (2000a, 2005). Os mereremei não são o único ritual de nominação conhecido e praticado pelos Xikrin, muito pelo contrário. Vários rituais, referidos a tipos de nome diferentes (Bep, Koko, Nhok etc.), podem ser feitos, mas os Xikrin do Bacajá parecem ter simplificado atualmente seu complexo ritual, confirmando todos os nomes no mereremei. Para descrições de outros rituais de nominação entre os Xikrin, ver Vidal (1977) e Giannini (1991). Para uma descrição do mereremei na aldeia do Bacajá, ver Cohn (2000a). 
lenha e pedras novas, para renovar o forno de pedras. Assim, sem o aporte feminino para o banquete festivo, não haveria nem festa, nem confirmação de nome, nem festa bem-sucedida, em que todos/as dançam e cantam forte e se fazem alegres.

Não é apenas com os alimentos que as mulheres promovem o crescimento e o fortalecimento das crianças, bem como proporcionam a beleza de todos e das aldeias. Afinal, são elas as pintoras entre os Xikrin, levando sempre a marca da "mão de pintora", como nominado por Vidal (1991), com a mão direita permanentemente enegrecida pelo uso do jenipapo. Assim, elas cuidam de manter todos devidamente pintados - o que é um sinal propiciador de saúde, beleza e alegria, atribuindo-se ao não estar pintado o contrário, associado à doença e à tristeza do luto, momento em que as pinturas são interditas. Crianças, mulheres, rapazes e homens casados são pintados diferentemente e em ocasiões diversas: em casa, para as crianças; em reuniões das mulheres pintoras, quando se pintam umas às outras; e de novo em casa, para os homens desde quando têm idade de casar (os menorony); apenas extraordinariamente homens se pintam, no mato, com jenipapo, mas, neste caso, apenas espremem o suco da fruta em seu corpo a partir dos ombros, criando uma padronagem não gráfica, não simétrica, com outro grafismo completamente diverso do das mulheres.

Além do jenipapo, as mulheres manuseiam também o urucum, o óleo de babaçu e as resinas, que compõem a pintura feita nas aldeias em tempos não festivos. Elas usam, ainda, além dos dedos, que podem gerar lindos padrões geométricos, uma tala de buriti especialmente preparada por elas mesmas para a pintura, a fim de obter padrões ainda mais refinados e cuidadosos. Assim, toda mulher casada e com filho - momento em que começam a se pintar entre si e a suas crianças, fazendo com que ser mãe signifique ser pintora também -, mantém um arsenal de frutos daqueles materiais. Além de serem usados em casa, esses materiais devem sempre estar à disposição quando a mulher é chamada a uma reunião de pintura, na qual mais jovens se pintam entre si, com um motivo único previamente acordado, e as mais velhas, também entre si, com outro motivo, também previamente acordado. Aos maridos, cada mulher pinta com um motivo que lhe apraz. E às crianças, as pinturas são feitas mais livremente, como já apontava Vidal (1992), o momento de maior criatividade da mulher pintora, com motivos variados, mas que são também as mais laboriosas e cuidadosas.

Mostrei, em outro trabalho, como a pintura das crianças muda de acordo com os momentos em que ela vai tendo seu corpo fortalecido (tôx) e quando vai demonstrando habilidades específicas, como a de andar e de falar autonomamente (Cohn 2000). A pintura, como vimos com a ingestão 
de comidas, também respeita uma gradação de perigo e de potência dos materiais, sendo o urucum o primeiro a ser usado, ainda na fase de recém-nascido, seguido do jenipapo, primeiro aplicado apenas com os dedos, até a pele estar dura ( $k a ̀$ tôx), e depois com a tala, em complicados padrões geométricos e simétricos. Somente quando começam a andar e a falar que sua pintura ganha os mesmos recortes dos que serão usados a vida inteira - no colo, na batata da perna e no braço -, quando também começam a receber a resina cheirosa na cabeça, com a feitura da primeira tonsura. Modo de embelezar e de acarinhar, a pintura é também maneira de prevenir e moldar - os espíritos dos mortos (mekaron), ávidos por reter a criança com eles, não gostam dos cheiros emitidos pelo urucum e pela resina, e evitam se aproximar da criança, sendo a fala atrativa e o toque as duas grandes armas para convencer as crianças a irem com eles. Mais recentemente, Demarchi (2014) enfatizou também, além desse aspecto profilático e preventivo, o de moldar o corpo da criança.

A pintura, todavia, não vem sozinha nos adornos dos corpos, vindo com a plumária e uma grande quantidade de ornamentos, como colares, braceletes, perneiras, tornozeleiras etc. ${ }^{14}$ Muitos desses adornos - principalmente aqueles que envolvem penas e palhas - são feitos pelos homens, porém vários que envolvem cordões de algodão - as perneiras e tornozeleiras, por exemplo - são feitos pelas mulheres. Os homens fazem, ainda, uma série de adornos com o algodão fiado pelas mulheres, como o cinturão vermelho usado pela menina púbere antes de casar e ter filhos. A ênfase na plumária e a sua exuberância nos levariam a esquecer, se não fizermos um esforço, da participação feminina na confecção de adornos. Quando é dia de festa, todos, menos os que a dão - os krareremei, no caso que citamos, por exemplo -, estão ricamente pintados e adornados. Essa é parte fundamental também para se fazer uma festa bonita, que seja forte e deixe a todos alegres. Essa ornamentação festiva não seria completa sem a participação das mulheres.

Além do mais, como demonstramos em outros trabalhos (Cohn 2000, 2010a), as crianças são as únicas vistas com seus ornamentos completos no dia a dia da aldeia, que é um modo de marcar as suas novas habilidades e o seu crescimento, assim como de promovê-lo, e também uma maneira de mostrar, deixar ver (amerin), as prerrogativas que cada uma delas possui (e que os Xikrin do Bacajá chamam de kukradjà). As crianças podem ser vistas, então, a qualquer momento, e sem que toda uma categoria de idade esteja pintada, mas a cada nova pintura, com todos os seus adornos - os que são

14 Cf., para se ter uma imagem dessa diversidade, Silva \& Gordon (2011). 
adornos comuns, me kuni nhõ kukradjà, e os que são delas, me’õ nhõ kukradjà, inhõ kukradjá. Assim, a espetacularidade e a opulência dos rituais podem ser vistas a todo momento no corpo das crianças, em uma combinação de pinturas e adornos que lhes foram feitos por seus pais e mães, ou avós, um modo de cuidado e de aparição de suas prerrogativas.

Atualmente, as mulheres têm se dedicado também à confecção de peças de miçangas pulseiras, colares e brincos -, as quais conseguem dos kuben ou adquirem com suas rendas, e que exigem que sejam da melhor qualidade, sempre. Multicoloridos, como a plumária, escapando dos usos iniciais que remetiam ao preto e ao vermelho das pinturas corporais e das tinturas do algodão com jenipapo e urucum, atualmente todos na aldeia podem ser vistos portando pulseiras, colares e brincos. Esta é uma manufatura feita especialmente pelas mais jovens - ao contráio das demais -, que costumam ornar corpos das crianças, destinada para filhos/as e irmãos/ãs, sendo que essas mulheres fazem esses objetos para si ou como presentes para seus maridos. Um novo e muito apreciado modo de ornar corpos, objetos dos quais só se desfazem quando há doença - quando têm que ser retirados - ou na morte pelos enlutados, que, aliás, os doam para quem morre, já que a família enterra junto ao cadáver, ornado com miçangas e ao lado de seus pertences, todas as suas miçangas ${ }^{15}$. Uma nova maneira de embelezamento e de marca de vida, saúde e alegria.

\section{FAZENDO COLETIVOS, FAZENDO POLÍTICA, FAZENDO GUERRA}

De fato, o tema de fazer coletivos já apareceu neste texto com o fazer ritual, além, é claro, do trabalho constante de fazer beleza e corpos. Concentremo-nos, entretanto, em outra cisão recorrente na etnologia quando se trata de gênero - a de que as mulheres estariam fora da "arena política”. Isso aparece no olhar não indígena como muito recorrente para os Jê, em que a existência de uma Casa dos Homens, em que se fazem reuniões e a oratória masculina, parece não só fazer crer em uma arena política decisória, como, consequentemente, parece também retirar as mulheres desse processo

15 Vidal (1977) já colocava em questão o tema dos objetos industrializados na ocasião de mortes. Porque, se todos os pertences de quem morre são com a pessoa enterrados, há décadas, espingardas, panelas de aço etc. eram muito difíceis de serem achadas. Ela narra um episódio em que a família enlutada lhe parece ser saqueada pelos demais, em um movimento desordenado, e percebe que esse acaba por ser um novo serviço funerário, o de despossuir, e desubjetivar, os objetos antes pertencentes a entes queridos, mas perdidos, evitando, assim, que tenham que ser enterrados. Cada vez mais, entre os Xikrin do Bacajá, objetos industrializados são enterrados junto ao cadáver, ficando a espingarda de um caçador pendurada sobre seu túmulo, por exemplo, ou as panelas de inox penduradas acima do túmulo de uma mulher, mas as miçangas, em todos os enterros que vi, são todas enterradas junto ao corpo. 
decisório e político ${ }^{16}$. Também recorrentemente se afirma, a partir do concentrismo espacial, que, quanto mais longe das casas, mais masculino é o domínio, e que, portanto, apenas os homens poderiam se movimentar e lidar com as florestas e seu além, os mundos dos espíritos, dos inimigos e do kuben, do não indígena (Giannini 1991).

A partir de um recurso voltado à história, em que debato a parte das mulheres nas guerras, e de uma discussão das atividades recentes de iniciativa das mulheres xikrin, as menire, buscarei mostrar que elas também produzem coletivos neste sentido, o político, de que foram por tanto tempo excluídas nas análises.

A começar, como mostrei em outros trabalhos, a maior produtividade da guerra era o trazer coisas de fora (myja o bôx) para compor o kukradjà, que, consoante a este argumento, deve ser sempre renovado para manter sua potência. De fato, o maior problema posto aos Xikrin quando aceitaram não mais fazer guerra era o fato de ter que achar, ou potencializar, outros modos de trazer novas coisas - cantos, cultivares, danças, adornos, nomes etc. - para renovar e potencializar aquilo que os faz ser o que são, Mebengokré (Cohn 2005). Se as mulheres não iam para a guerra, sua participação nesse tipo de evento é dupla - porque as cativas dos inimigos têm sua alteridade retida na convivência o tempo suficiente para ensinar novas coisas, e só depois são tornadas mebengokré, portando as pinturas, falando a língua, exemplarmente, para serem aparentadas pelo casamento. Mas também porque as mulheres faziam parte de um importante botim de guerra - sementes e plantas. Cada mulher, desde que se torna mãe, tem sua roça - mais frequentemente no plural, várias roças, a velha, que ainda dá alguns tubérculos, a nova, em pleno uso, a que acaba de plantar, o bananal... -, sempre diferente das roças das outras mulheres, sendo composta por vegetais que ganharam de outras parentes (em especial, a mãe), que trocaram com aliadas, em situações diversas - para além das miçangas, novas sementes e novas variedades de plantas a serem cultivadas sempre foram um dos pedidos mais recorrentes que recebi das mulheres -, mas também pelas variantes que roubaram dos inimigos, retirandoas das roças abandonadas depois de um ataque guerreiro (Cohn 2011). Assim, o ideal de uma boa

16 Argumento aqui que essa arena política é uma ficção, já que não só é uma opinião o mais comum possível, que inclui a das mulheres, mas que a oratória tem seu clímax na oratória do chefe, que nada mais é do que a expressão da fala comum (Verswijver 1992; Cohn 2006). É verdade que os Xikrin remetem às mulheres a culpa primeira do fracasso das negociações e decisões, dizendo que elas "fofocam demais", como traduzem para o português, ou fazem a fala ruim, kaben punu. Mas o kaben punu não é uma prerrogativa exclusivamente feminina, e qualquer decisão que não se consiga tomar coletivamente foi corrompida por ele, sem distinção de gênero, assim como essa é a razão mais recorrente para as lideranças reclamarem de seu fardo - ter que lidar com a má fala (Cohn 2000a). Acrescento, ainda, que Lea (2007) chama a atenção para o choro ritual, feito apenas pelas mulheres, e - como no caso da oratória masculina - pelas mais velhas, o qual é uma versão da oratória pública, tão formalizada quanto, embora entoado em espaços menos públicos e se remetendo às lembranças sobre a pessoa falecida. 
roça, porque produtiva, bem cuidada e que rende muitos frutos, também só pode ser realizado com a diversificação das plantas lá cultivadas, em cada uma delas e por cada mulher. Isso explica porque, no consumo das batatas assadas no rio, as mulheres comentam as variedades das batatas umas das outras, dissertando sobre seu tamanho, sua cor, seu sabor, as comparando, elogiando etc.

Mas, finda a guerra - como conflito armado -, os Xikrin (e as Xikrin) tiveram que buscar novas formas de fazer essa diferenciação em seu kukradjà, que sem ela perdesse potência. Isso significa uma intensificação também das relações de aliança política, inclusive com outros povos e com os não indígenas, que permite uma troca e uma circulação de novidades. E isso não é feito só pelos homens, mas também pelas mulheres.

Atualmente, as menire estão buscando novas formas de mobilização política reconhecidas pelos kuben, fazendo projetos e se inserindo em atividades de intercâmbio e geração de renda a partir de seus kukradjà, os menire nhõ kukradjà, o kukradjà das mulheres, como têm enfatizado. É interessante a ênfase que elas dão às suas potências femininas e à feminilidade como potência. Isso elas têm feito em suas atuações nas aldeias, nos debates e nas interações com as diversas equipes que se propõem a realizar projetos com os Xikrin, seja em nome da mitigação e compensação de impactos da construção da UHE Belo Monte - até 2017, eram equipes de 13 eixos de atividades -, seja em nome de "parcerias" (como chamam os Xikrin, em português) em atividades produtivas que gerem rendas, como organizações não governamentais (ONGs), seja na confecção e nas etapas formativas do projeto ligado ao Plano Nacional de Gestão e Manejo de Terras Indígenas (PNGATI), seja com as pessoas que vão para as aldeias, como as antropólogas. Estão o fazendo também fora das aldeias, na participação ativa em reuniões sobre impactos e direitos, na formação como agentes ambientais no projeto PNGATI, na participação de feiras de artes e artesanatos, nos intercâmbios ${ }^{17}$.

A atuação das menire é bipartite também por ter duas frentes: de um lado, elas têm se afirmado as verdadeiras mantenedoras e protetoras da Terra Indígena, argumentando que suas roças fixam e marcam o território, e que sua presença nas aldeias, quando os homens estão tanto tempo fora, nas cidades, faz a real vigilância e proteção dessas terras. É um argumento forte e ousado, que desvia a fiscalização e a vigilância das terras da caça e da movimentação dos homens próximos das fronteiras, e a aloca na terra firme,

17 Pude acompanhar alguns desses eventos e me detenho mais nestes que vi de perto. Fui mantida informada não só por elas, as menire, por meio das redes sociais, mas também pelas diversas pessoas que com elas colaboravam, que citei em meu agradecimento geral, mas que aqui novamente agradeço, por me permitirem um quadro mais amplo dessas ações. 
na roça, na fixação. De outro, elas têm reclamado mais participação nos debates públicos, e uma organização própria com a representatividade.

Eu mesma comecei a ver esse movimento quando, participando da equipe que avaliou os impactos ambientais decorrentes da UHE Belo Monte, e viajando pelas aldeias com Isabelle Giannini, mostrando a ela os impactos previstos pela UHE e ouvindo suas avaliações acerca deles que foram para o relatório final (Estudo de Impacto Ambiental EIA), já em 2009, chegando à penúltima aldeia antes de sair da Terra Indígena, a Potikrô, as mulheres levantaram e foram registrar seus depoimentos em nosso gravador. Essa foi a primeira vez que eu as vi tomarem essa posição, mas se revelou o que efetivamente era: a primeira de muitas.

Para melhor compreendermos essas novas atuações das menire, será importante entendermos os enormes desafios por que passam os Xikrin hoje. Em síntese, o que tem acontecido é que, após um período de muitas perdas demográficas, guerras intensas e crescentes, além de doenças, os Xikrin, em meados do século passado, decidiram-se por aceitar o estabelecimento de relações pacíficas com o Estado nacional, nos termos desse "contrato", dados pelas equipes de atração.

Decidir por isso significou o fim das guerras, a sedentarização e a sua reinvenção como um povo não mais guerreiro. Acontece que a guerra era meio para outros fins - nominalmente, a guerra xikrin era altamente produtiva na renovação de seu kukradjà, que, por seu turno, é meio de fazer sempre renovados, fortes e belos Mebengokré, em renovados rituais e pessoas, com novos nomes para circular e compor pessoas, novos adornos, danças e cantos para as festas e para compor as pessoas - que são feitas também com seus kukradjà -, renovadas e diversas roças etc. Significou também rever suas relações com antigos inimigos, tornados aliados, entre eles os não indígenas, os kuben, agora corresidentes na aldeia do Bacajá, aliados nunca aparentados, mas presumivelmente fonte de novas coisas, como se apresentaram de início, embora logo tenham passado a argumentar que, por falta de recursos, não mais os podiam fornecer. E, por fim, significou "fazer a guerra por outros meios”, na expressão de Menget (1985), ou seja, transformar a produtividade da guerra, meio de trazer novas coisas (myja o bôx), em trocas em encontros pacificados com outros indígenas. Com estes, por vezes se aliavam e por vezes se inimizavam, mas tinham se transformado em aliados, com quem trocavam adornos, armas, sementes e mudas, cantos, danças, em encontros como as formações conjuntas de agentes indígenas de saúde e professores indígenas, realizados na cidade de Altamira, que reuniam os diversos povos indígenas da região (Cohn 2005). Novos cantos, 
novas danças, novos adornos eram então trocados ou vinham em mídias, como $\mathrm{CD}$, DVD, com cantos e danças dos outros povos, em especial os demais Jê e os Xikrin do Cateté, que forneciam gravações de festas, vistas e ouvidas por dias sem fim. Era, como argumentamos, um outro modo de fazer guerra, uma guerra sem inimigos, mas que mantinha a inimização na possibilidade de trocas e produção de pessoas e de coletivos (Sztutman \& Cohn 2003).

Este período foi, por muito tempo, instável, em que a guerra parecia poder irromper a qualquer momento, como quase ocorreu com os Parakanã em meados da década de 1990, consequências que, por vezes, temiam, mantendo-se a dúvida sobre se isso não acarretaria serem fadados a produzir Mebengokrés enfraquecidos (Cohn 2005). Mantinham, entretanto, uma esperança e uma projeção de futuro possíveis nas evidências da permanência de indígenas em isolamento voluntário, que os assustava - porque talvez os levasse de volta à guerra -, mas mantinham viva a ideia de que poderia haver ainda os mebengokre djwy, os Mebengokré verdadeiros, não pacificados, que não teriam se rendido a essa opção $\left(\right.$ Cohn 2005, 2006) ${ }^{18}$. Este foi também um período em que souberam se reinventar, e no qual obtiveram conquistas que lhes assegurava que a decisão tomada tinha sido a boa decisão, com o crescimento demográfico - o finado Bep-djô me dizia que "agora a aldeia está bonita, com crianças correndo pelo pátio" (Cohn 2000:12) -, o controle das doenças que os dizimavam e a demarcação da Terra Indígena Trincheira-Bacajá, em 1995.

Atualmente, porém, essa reinvenção - e sua possibilidade - parece ter ganhado outros contornos, trazendo outros desafios. Se a aceitação do contato esteve, historicamente, ligada ao aumento da exploração extrativista em seu território, que levou a uma aceleração das guerras e à construção da Transamazônica, que os cercou de não indígenas, seja pela obra em si, seja pela política de colonização da Amazônia levada a cabo pelo Instituto Nacional de Colonização e Reforma Agrária (INCRA), loteando terras próximas de suas áreas de movimentação para os chamados “colonos" (Fisher 1991, 2000; Tseouliko 2018a), no século XXI a construção da UHE Belo Monte foi, gradativamente, uma quebra desse "contrato" inicial. Com um processo de licenciamento ambiental

18 Gordon (2005) faz um comentário neste mesmo sentido para os Xikrin do Cateté, que estariam se perguntando se, afinal, esse consumo inflacionado (seguindo os termos do autor) dos bens e das mercadorias dos kuben não estaria acelerando demasiadamente a máquina da diferenciação necessária, e trazendo o risco de, usando tanto as roupas, comendo tanto as comidas e utilizando-se tanto os remédios dos kuben, virarem, definitivamente, kuben. Em Cohn (2005), mostro que as alternâncias de identidade fazem parte das narrativas dos Xikrin, mas que o perigo está em parar a alternância, assim como nas relações entre inimizade e aliança. São esses os riscos aventados pelos Xikrin hoje, em algo que não deve ser confundido com culturalismo, mas formula o devido equilíbrio entre manter a diferenciação e não se ver preso nas engrenagens do mecanismo que mantém tal alternância. 
crivado de problemas, em que o prometido era constantemente descumprido (Oliveira \& Cohn 2014; Mantovanelli 2016a, 2016b), e, agora, com a iminência da construção da mineração a céu aberto Belo Sun, cujas áreas de prospecção invadem a Terra Indígena, os Xikrin passam a viver a "era dos impactos" (Mantovanelli 2016a).

É a partir deste momento, que teve seu início em 2009, com a realização dos Estudos de Impacto Ambiental - em que os Xikrin do Bacajá tiveram, pela primeira vez, e por clara omissão do Estado, a notícia dos impactos advindos do novo projeto de aproveitamento hídrico da obra (Cohn 2010b) -, que os Xikrin do Bacajá tentaram empreender com mais afinco uma nova forma de negociação, a das reuniões - sem sucesso, e os levando a uma "crítica da política dos brancos", pela qual a palavra não vale, os documentos não têm validade e as reuniões são vazias de efeito (Mantovanelli 2016a). De fato, tentaram, e continuam tentando pela última década, fazer valer essa nova estratégia, tendo ensaiado movimentos de inimização aberta, como a ocupação dos canteiros de obras, junto a outros povos indígenas, que, no entanto, redundou em mais negociações e descumprimento dos compromissos.

Além da iminência de Belo Sun, os Xikrin agora têm lutado contra uma nova onda de invasão de suas terras - que havia sido prevista desde os Estudos de Impacto Ambiental, e em diversos documentos, pois a construção da hidrelétrica levou uma grande população para a região, que ou não conseguiu trabalhar na obra ou foi desmobilizada quando ela acabou -, sem que a vigilância desse espaço, um compromisso da FUNAI, em convênio com o empreendedor, a Norte Energia, fosse realizada a efeito. Além disso, o Plano Xikrin, denominado Aben kaben mari mex, uma expressão que traduzo como um acordo entre todos os residentes da TI, realizado a partir do projeto ligado ao PNGATI, com recursos do Fundo Amazônia e a cargo da ONG The Nature Conservancy (TNC), não redundou em ações efetivas. Tampouco por essa via os Xikrin conseguiram recursos para a logística e a segurança de projetos de fiscalização e vigilância, como expedições pelas terras e sua "fronteira seca", hoje ladeada por fazendas e vilas, a reabertura da picada de demarcação, tomada pelo mato, e a contratação, por eles demandada, nas equipes que trabalham nos postos de vigilância construídos pelo convênio FUNAI/Norte Energia, sob argumento de que eles não teriam formação escolar suficiente. Esta é uma explicação esdrúxula, claro, mas, aos seus olhos, ainda mais incompreensível, dado que eles passaram, com muito orgulho e afinco, por um processo de formação de Agentes Ambientais Indígenas, com a expectativa de que isso ao menos lhes abrisse essas portas formais.

Enfim, são estes desafios que atualmente 
enfrentam as menire xikrin. E é a partir deles que tomam novas atuações e atividades em mãos. Como disse, uma delas é exatamente se marcarem como as verdadeiras guardiãs da Terra, onde criam e nutrem, ao ficarem nas aldeias, ao criarem e fazerem crescer as crianças, ao cuidarem da terra e ao plantarem ${ }^{19}$. Questão nova para todos eles, evidentemente, porque sua história é de pessoas que se movimentam, andam, fazem excursões por longos períodos do ano e retornam a aldeias apenas para a colheita e as festas, mas que agora viram, de um lado, sua liberdade de movimento tolhida e, de outro, a garantia de uma rica e extensa Terra Indígena. Se há uma dupla inversão, de um lado, dada pela sedentarização, as mulheres respondem com outra - se alguém deve guardar as terras conquistadas, esse alguém somos nós.

Mas isso se faz em conjunção com outra frente de luta: a de se fazer reconhecer nas negociações com os não indígenas (kuben), a de ter uma atuação própria e independente das políticas feitas pelos homens Xikin, que muito têm criticado, e a tomar frente na geração de renda para si e para suas famílias. Foi assim que buscaram a parceria das antropólogas e da FUNAI para a realização de um projeto, submetido e aprovado para o Plano de Desenvolvimento Regional Sustentável do Xingu (PDRS Xingu), em que se propunham a aprender a construir uma associação e ter, assim, autonomia para elaborar, submeter e gerenciar os seus próprios projetos.

A partir de uma primeira proposta, com uma instrução formalizada das menire para construir essa associação - oficinas, conhecimentos de contabilidade e prestação de contas, visitas a cartórios, reuniões nas aldeias para decidirem juntas o que fazer, que culminaria em um projeto a ser encaminhado por uma associação composta neste processo -, as menire, em assembleia, decidiram aprender a fazer projetos no próprio fazer - uma maneira absolutamente condizente com o modo mebengokré de aprender, que discuto em Cohn (2000) -, estratégia que elas chamaram de Prin-ne myja mari mei, ou seja, saber/ aprender bem as coisas. Com esse recurso, se não saiu a associação, saíram diversas atividades, em andamento até hoje. Uma delas foi a produção de um livro a partir de fotografias para o que tiveram, essas sim, a instrução formal, com oficinas de fotografia, intitulado "Terra Indígena TrincheiraBacajá: Menire nhõ kukradjà mextere. A força e a beleza do conhecimento das Mulheres Xikrin", que ganhou uma edição financiada com estes mesmos recursos e reúne fotografias tiradas e selecionadas por elas a partir dos afazeres e saberes femininos que quiseram mostrar, com textos explicativos também

19 Sobre a territorialidade Xikrin, ver Tseouliko (2018a); sobre a mobilidade histórica, ver Vidal (1977), Fisher (2000) e Cohn (2005) 
feitos por elas, e contando com o apoio da equipe. Além disso, foram feitas as primeiras etapas de uma atividade que vem crescendo e sendo apoiada por diversos outros projetos e financiamentos, como o feito em parceria com a TNC, em outro edital PDRS Xingu, o processamento do óleo de babaçu.

Processar óleo de babaçu é uma das atividades frequentemente realizadas pelas mulheres e, como já explicamos, esse produto é usado cotidianamente para o embelezamento de corpos e cabelos. O óleo é retirado do coco do babaçu, coletado nas matas e, até recentemente, processado por cada mulher, ou grupo de parentas, em suas casas. Com os projetos, foi adquirida e montada em uma das aldeias uma máquina de processamento do óleo; também foi elaborada uma marca (Menire) e um logo (no logo, uma estilização de um rosto de mulher com a tonsura e a pintura facial, que, como me conta Thaís Mantovanelli, foi muito debatida e criticada pelas menire, por lhes lembrar mais um espectro do que um rosto de mulher ${ }^{20}$, mas, afinal, aceita, com algumas modificações).

Nas etiquetas, lê-se, acima e abaixo do logo, "óleo de babaçu - produzido pelas mulheres xikrin", e um pequeno texto diz: "o óleo de babaçu é tradicionalmente usado pelas menire (mulheres xikrin) para fins de embelezamento e hidratação capilar, sendo aplicado da raiz às pontas. Também pode ser usado para fritar e temperar alimentos diversos como arroz, carne, entre outros". O texto enfatiza, desse modo, o uso "tradicional" do óleo, que lhe dá valor, ampliando sua aplicação como sugestão para os não indígenas, primeiros consumidores projetados, já que o uso culinário não é até o momento feito por elas (embora possa vir a ser, tendo em vista, como já vimos, o maior consumo de alimentos cozidos e fritos).

Essa atividade permitiu também uma série de intercâmbios, inclusive com os extrativistas da Reserva Extrativista (RESEX) da região, em que as menire aprenderam um pouco mais desse modo não indígena, mas sustentável, de produzir e mercantilizar o óleo. Além disso, o projeto recebeu menção honrosa na categoria Empreendimentos Rurais, do prêmio "Saberes e Sabores 2018", oferecido pela Organização das Nações Unidas para Agricultura e Alimentação (FAO).

Se essa atividade tem tido grande sucesso, tem também trazido desafios. Um deles é a questão de como todas poderiam se beneficiar da máquina, dada a extensão da Terra Indígena, a quantidade de aldeias e sua distância, e a necessidade de cada mulher de transportar seus cocos de babaçu para

20 Cf. Cohn (2010a), para uma discussão acerca da pintura e dos adornos dos corpos de mortos para o enterro, que é o que estava em jogo aqui. Ressalto que uma das brincadeiras que sempre ouvi em pequenos intervalos que fazíamos para nos aquecer durante as danças noturnas nas festas, quando, todas ornadas, nos reuníamos ao redor de um fogo que nos iluminava os rostos, era se eu não estava com medo, porque parecíamos todas mortas, mekaron. Como os mekaron, de fato, visitam as aldeias para as festas (Cohn 2000a), a brincadeira era, como costuma ser, séria, e o medo, fundado. 
as reuniões em que usam coletivamente a máquina processadora, desafios que a equipe de apoio, não indígena, tem buscado solucionar com elas. Vêse que está em jogo a mesma lógica do forno de pedra: se todas usam as máquinas, cada uma o faz com sua matéria-prima e levando para casa apenas o que produziu de óleo com os cocos que levou e quebrou manualmente, em oposição a uma produção coletiva e repartida igualitariamente. Mas está em jogo também outra relação que tem desafiado os Xikrin, e as menire: a relação entre as, agora, muitas aldeias, e a decisão sobre onde fica a máquina processadora e quem cuida dela, um trabalho remunerado. Atualmente, está em curso a discussão sobre a possibilidade de montar uma máquina na aldeia do Bacajá, de modo a se ter uma máquina no "Alto Bacajá" e no "Baixo Bacajá"11.

De fato, o aprender fazendo projetos tem tido sucesso. Em aula no curso de formação de Agentes Ambientais Indígenas, sobre projetos, NgrenhKaràti compartilhou com colegas que projetos têm que prever custos de manutenção - o que ela aprendeu, efetivamente, ao acompanhar as atividades de processamento do óleo de babaçu, por diversas vezes interrompida por falta de recursos para consertar a máquina, quando ela quebrava.

$\mathrm{Na}$ aldeia do Potikrô, as mulheres decidiram fazer uma roça coletiva, para a qual fizeram um projeto. Já dissemos que as roças são abertas pelos casais, desde que tiveram seus primeiros filhos, mas roças coletivas não são uma inovação em si na TI Trincheira-Bacajá - ao contrário, por diversas vezes, servidores da FUNAI incentivaram a abertura de roças coletivas que fossem "dos chefes", "para a comunidade", e, para tanto, proviam ferramentas, mesmo que elas nunca dessem certo (Fisher 1991, 2000; Cohn 2005). E elas não davam certo por diversos motivos, todos ligados a uma certa imagem de comunitarismo e liderança ${ }^{22}$. Assim, nem a coordenação dos trabalhos nem a plantação e a colheita comum em uma roça comunitária eram possibilidades aos olhos dos Xikrin. Mas, mais do que isso, como vimos, as mulheres despendem muito esforço para garantir a diferenciação de suas roças - e uma roça coletiva seria a mistura dessas plantas, tão cuidadosamente mantidas separadas.

Certamente, os servidores da FUNAI poderiam, neste aspecto, esperar melhores resultados se distribuíssem novas sementes e mudas, o que seria muito apreciado, embora minha previsão fosse de

21 Sobre a territorialidade e as diferenças entre as aldeias e essa divisão, cf. Tseouliko (2018a).

22 Pelo comunitarismo, esperava-se que as lideranças assumissem a coordenação dos trabalhos na roça e a distribuição dos produtos, embora, mesmo que elas fossem, em momentos cruciais, distribuidoras de bens e alimentos, quando se refere à roça, nunca o é pela produção coletiva do que compõe a colheita, mas porque, após um dia de colheita coletiva nas diversas roças, quando, por exemplo, o milho recém-amadurece, cada mulher separa um tanto do milho para deixar com os membros do casal reconhecidos como lideranças, benadjwyry. 
que elas iriam acabar se dispersando pelas roças de cada mulher. Mas a dupla coordenação - do chefe de posto, que toma a iniciativa e fornece os meios à liderança, a quem delega a tarefa - não poderia, de fato, funcionar.

Quando as menire tomaram, elas mesmas, a iniciativa de fazer uma roça coletiva feminina, e se buscou financiamento e apoio logístico para tal, planejando fazer farinha para a venda e ter renda para suas famílias, a empreitada prometia ser mais bem-sucedida. Porém, após um trabalho dedicado de limpeza da área escolhida, feito por elas ${ }^{23}$ - embora, em dado momento, requisitando auxílio dos homens, por conta do trator que existe nessa aldeia -, e o plantio, feito com um misto de manivas buscadas em outras aldeias e aquelas que cada mulher levou de suas roças (Tseouliko $2018 b)^{24}$, "no final das contas, a roça coletiva das mulheres se transformou em um conjunto de roças individuais, ou seja, roças destinadas ao consumo doméstico" (Tseouliko 2018b:92).
As menire têm também mantido iniciativas mais ou menos pessoais ou familiares de geração de renda, além da venda de pulseiras, colares e brincos para outros indígenas com quem convivem em intercâmbios, reuniões e eventos, como oficinas de formação, e especialmente para os não indígenas, os kuben, que são, aliás, os maiores e mais demandados fornecedores das próprias contas. Elas têm também pintado panos, que podem ser panos inteiros, como painéis, camisetas ou bolsas, que elas mesmas confeccionam, quando têm máquina de costura ${ }^{25}$. Estes produtos são igualmente vendidos nas mesmas ocasiões citadas, e também junto aos produtos da marca Menire, em feiras que têm sido realizadas na cidade de Altamira. Essa renda, então, é de cada pessoa, sendo utilizada para a aquisição de roupas, em especial o famoso vestido das Xikrin (e Kayapó), de comida nos mercados e de muitos brinquedos, comidas, roupas e calçados voltados para as crianças.

23 Quando um casal abre uma nova roça, são os homens os responsáveis pela limpeza e as mulheres, pelo plantio, cuidado e colheita.

$24 \mathrm{Em}$ algo parecido ao que relatei anteriormente para as roças de cada casal e que potencializa sua diferenciação, dado que esse movimento conjunto, de buscar manivas fora e de compor com manivas de cada mulher que participava do plantio da roça coletiva, torna a roça de cada casal, como a de cada mulher, única, neutralizando o problema de indiferenciação da roça de cada mulher.

25 Máquinas de costura foram demandadas diversas vezes em "projetos”, e um deles, feito pela FUNAI junto a TNC, e denominado como um dos quatro projetos "pequeno GATI", se dedicou exatamente à aquisição desses equipamentos. Não tenho dados vindos dos que realizaram o projeto, mas posso afirmar ter visto poucas dessas máquinas nas aldeias. Cf. Tseouliko (2018b), para um debate sobre esse projeto e a participação das mulheres em diversas outras iniciativas. 
Por fim, evidencio aqui que, nos últimos anos, marcados por grande aceleração nas mudanças de lugares das aldeias e nas suas recomposições, as mulheres têm sido um dos eixos importantes dessa reorganização. Antes de falarmos nisso, lembro que a mobilidade, a mudança de aldeias e a contínua recomposição destas foram a marca dos Mebengokré antes do contato (Vidal 1977; Fisher 1991; Verswijver 1992; Cohn 2005, Tseouliko 2018a). Uma das mudanças desde a corresidência e a aliança política com os kuben foi a sedentarização, a vida em uma única aldeia, a do Bacajá, e a demarcação da terra, que, se lhes deu garantia de vastas e ricas terras, tolheram, como já discutimos, seus movimentos. A necessidade de se manter próximo dos recursos vindos dos kuben - ou seja, da casa do chefe de posto, da "farmácia" (em especial, nos primeiros anos, quando a memória das terríveis doenças ainda era muito viva) e da escola - e a dificuldade, por muito tempo, de negociar novos serviços desse tipo para novas aldeias ajudaram a mantê-los vivendo juntos, em uma única aldeia, mas esta, não podemos esquecer, era uma situação extraordinária.

A primeira cisão de aldeias ocorreu na década de 1980 (Fisher 1991), e separou basicamente os Xikrin contactados daqueles que foram residir com eles depois de terem feito parte das equipes de atração, e casaram-se com mulheres dos grupos contactados. Essa foi a formação do arranjo aldeão da Bacajá e da Trincheira (esta atualmente renomeada Potikrô), reunidas novamente na demarcação da terra, que, por isso, ganhou esse nome, Terra Indígena Trincheira-Bacajá. Em 2009, quando da realização dos Estudos de Impacto Ambiental, eram quatro já as aldeias (Cohn 2010b); em 2010, quando da realização dos Estudos Complementares do Rio Bacajá, eram cinco (Mantovanelli 2016b); uma década depois, em 2019, são 17. Se essas cisões de aldeia são expressão do aumento do conflito nelas e entre elas, com os desafios que têm enfrentado, são também um modo de voltar a poder se recompor e mudar. Isso só foi permitido por um fortalecimento nas negociações com o Estado, em que as lideranças, para levantar as aldeias, garantiram, para além dos bons recursos de fertilidade do solo, caça e pesca, também serviços como de educação e de saúde e o reconhecimento oficial pela FUNAI e outras instâncias.

Elas são também um meio de proteger a terra. Uma vista pelo mapa atual da TI mostra que elas têm sido construídas próximo à "fronteira seca", que faz divisa com os fazendeiros, e não na região mais protegida, que faz vizinhança com outras Terras Indígenas. Este foi um meio também de potencializar e facilitar as relações, a troca e o trânsito para as 
vilas, cidades e a própria Altamira, onde estão os principais serviços que os atendem (as secretarias de educação e de saúde, a Casa de Saúde do Índio/ CASAI, o Distrito Sanitário Especial Indígena (DSEI), a Fundação Nacional do Índio/FUNAI e a Casa do Índio). Este é, além disso, um efeito da “Amazônia das estradas" (Tseouliko 2018a) que se cria com o fim da navegabilidade na Volta Grande do Xingu e no próprio rio Bacajá, e a abertura, pela Norte Energia, por meio do Plano Básico Ambiental, de estradas, que, se os Xikrin têm usado para as idas e vindas para fora da TI, o têm também para o trânsito entre as aldeias, e novos locais para as roças - desde o contato, feitas ao longo do rio e para caminhos de caça e coleta - que também tinham se concentrado ao longo do rio ${ }^{26}$.

Essas mudanças de aldeias e das composições das aldeias, rápidas e difíceis de se acompanhar, têm tido grande interferência das mulheres, que têm mudado em grupo de irmãs ou mães e filhas. Assim, voltamos ao ponto inicial do texto e, se expressamente são lideranças que reúnem novas aldeias, se sogros e genros coabitam - hoje, diria, é porque suas esposas e filhas decidem morar juntas.

Não importa de quem é a inicativa, e os rompimentos podem até ser narrados como desentendimentos no que seria a tal da arena pública, o fato é que homens só conseguirão se deslocar se suas esposas tiverem a garantia de se sentirem confortáveis e criarem bem seus filhos no novo lugar, e isso significa a garantia de recursos naturais e de serviços, mas também a convivência com suas parentas.

\section{CONCLUSÕES}

Este texto dialoga com muitos e muitas. Nele, busquei debater os vícios da bibliografia jê que nos impedia de olhar mais atentamente para as mulheres, o que elas efetivamente fazem e sua participação na produção de pessoas e coletivos mebengokré, e de seu kukradjà. $\mathrm{Na}$ realidade, isso só fica mais ressaltado quando pensamos que a única área em que elas se sobressaíram nos estudos etnográficos foi exatamente aquela em que elas têm domínio praticamente exclusivo - a pintura corporal -, ou em uma análise que busca inspiração no englobamento do contrário dumontiano. De resto, sua participação na formação de pessoas e coletivos tem sido obliterada nas análises, e este texto buscou mostrar que as mulheres

26 Como se demonstrou nos Estudos de Impacto Ambiental, e foi um dos principais argumentos para que se considerasse os Xikrin do Bacajá como diretamente atingidos pela UHE Belo Monte, tendo, anteriormente, a FUNAI acordado com a Eletronorte que eles seriam considerados indiretamente atingidos. Na ocasião, apontou-se também que esse se voltar para o rio era uma das consequências da sedentarização em uma aldeia às margens do rio, tendo sido historicamente os Xikrin um povo "da floresta" e dos igarapés (como se pode ver em Fisher 1991 e Tseouliko 2018a, 2018b). Assim, décadas e gerações dedicadas ao domínio - técnico e de conhecimentos - do rio seriam subitamente jogadas fora pela iminente seca do rio Bacajá, com a seca da Volta Grande do Xingu. 
efetivamente participam de forma complementar e inegável para fazer pessoas, corpos, aldeias, territorialidades, rituais, bem como na política e nas relações marcadas pela alteridade. Talvez este artigo tenha também pecado pela obliteração dos homens - leitores/as dirão. Mas, se o foi, foi somente para marcar a potência feminina na produção de pessoas e coletivos mebengokré e como, atualmente, essas mulheres, as menire xikrin do Bacajá, têm manejado essa potência, e sua feminilidade, para enfrentar os enormes desafios. Assim, parafraseando Ngrenh-djam Xikrin (2014), em texto sobre os impactos de Belo Monte, e para mostrar que a luta continua, para todos os Xikrin, as menire e a antropologia, concluo com um "fim sem fim".

\section{AGRADECIMENTOS}

Preciso agradecer a muita gente por este texto e essas reflexões. Em primeiro lugar, aos Xikrin, da Terra Indígena Trincheira-Bacajá, como um todo, pelo acolhimento e pela infinita paciência em me ensinar (e embelezar), em especial as mulheres, as menire xikrin. Entre elas, agradeço principalmente a Ngrei-Karàti, que tem sido uma companheira que muito me ensinou em várias das ocasiões narradas aqui; à sua filha Kokoté; a Ngrenh-djãm Xikrin (Rafaela), que há muito me tem provocado a pensar nessas questões; e a Nhoka, com quem viajei em
2017 pelas aldeias. Agradeço às minhas professoras e orientadoras Lux Vidal e Beatriz Perrone-Moisés, que muito me ajudaram a entender o vasto e rico mundo Xikrin; e às professoras Manuela Carneiro da Cunha e Aracy Lopes da Silva (in memoriam), que também, como as anteriores, me ensinaram sobre os Jê, sobre etnologia e sobre estar sempre na luta. À Isabelle Giannini, por ter vivido o começo de uma batalha que dura uma década e compartilhado a viagem e as reflexões sobre os impactos ambientais no rio Bacajá para os Xikrin. Agradeço, ainda, às minhas alunas (algumas já doutoras) Thaís Regina Mantovanelli, Stéphanie Tseouliko, Camila B. Beltrame, Ana Elisa Santiago e Jucimara Cavalcante, por terem me acompanhado nestas reflexões e nas diversas atividades compartilhadas, e se engajado com as menire em muitas das iniciativas que analiso aqui. Aproveito para agradecer não só à equipe de formadores do Curso de Formação de Agentes Ambientais Xikrin, como a todos os alunos, em especial às alunas Ngrei-karàti, Monook e Irekoti, ocasião em que, como todos os bons cursos, aprendi tanto, ou mais, quanto ensinei. Agradeço também a Estella Libardi de Souza, Rafaela Soldan, Gabriela Prado, Luciana Lima, Luciana Brandão e Leonardo de Moura que, na FUNAI ou atuando junto a diversas organizações não governamentais, tomaram parte desses projetos com as menire e conosco. 


\section{REFERÊNCIAS}

Bamberger, J. 1979. Exit and voice in Central Brazil: the politics of flight in Kayapó society, in Dialectical Societies: the Gê and Bororo of Central Brazil. Organizado por D. Maybury-Lewis, pp. 130146. Cambridge: Harvard University Press.

Beckerman, S. J. 1994. Hunting and fishing in Amazonia: hold the answers, what are the questions?, in Amazonian Indians from prehistory to the present. Organizado por A. Roosevelt, pp. 177-200. Tucson: University of Arizona Press.

Caiuby Novaes, S. 1986. Mulheres, homens e heróis: dinâmica e permanência através do cotidiano da vida Bororo. São Paulo: FFLCH-USP. (Série Antropologia, 8).

Cohn, C. 2000a. A criança indígena. A concepção xikrin de infância e aprendizado. Dissertação de Mestrado, Universidade de São Paulo, Departamento de Antropologia, São Paulo.

Cohn, C. 2000b. Crescendo como um Xikrin: uma análise da infância e do desenvolvimento infantil entre os Kayapó-Xikrin do Bacajá. Revista de Antropologia 43(2):195-222. DOI: http://dx.doi.org/10.1590/ S0034-77012000000200009.

Cohn, C. 2005. Relações de diferença no Brasil Central. Os Mebengokré e seus Outros. Tese de Doutorado, Universidade de São Paulo, Departamento de Antropologia, São Paulo.

Cohn, C. 2006. Discursos políticos e objetificação da cultura nos Mebengokré-Xikrin. Anais do $30^{\circ}$ Encontro Anual da ANPOCS.

Cohn, C. 2010a. A criança, a morte e os mortos: o caso mebengokré-xikrin. Horizontes Antropológicos 16(34):93-115. DOI: http://dx.doi.org/10.1590/S0104-71832010000200005. 
Cohn, C. 2010b. Belo Monte e processos de licenciamento ambiental: as percepções e as atuações dos Xikrin e dos seus antropólogos. R@u - Revista de Antropologia da UFSCar 2(2):224-251.

Cohn, C. 2011. Os Mebengokré e seus Outros do ponto de vista das mulheres, in Os Outros dos Outros: relações de alteridade na Etnologia Sul-Americana. Organizado por E. C. Lima, e L. Córdoba, pp. 57-71. Paraná: Editora UFPR.

Cohn, C. No prelo. Os vários modelos jê em Dialectical Societies. R@u - Revista de Antropologia da UFSCar.

Da Matta, R. 1976. Um mundo dividido. Petrópolis: Vozes.

Demarchi, A. 2014. Kukràdjà Nhipêjx: fazendo cultura: beleza, ritual e políticas da visualidade entre os Mebêngôkre-Kayapó. Tese de Doutorado, Universidade Federal do Rio de Janeiro, Departamento de Sociologia e Antropologia, Rio de Janeiro.

Dreyfus, S. 1963. Les Kayapo du Nord, état du Pará, Brésil: contribuition à l'étude des indiens Gê. Paris: Mouton \& Co.

Fisher, W. H. 1991. Dualism and its discontents: social process and village fissioning among the XikrinKayapó of central Brazil. Cornell: Cornell University.

Fisher, W. H. 2000. Rain forest exchanges. Industry and community on an Amazonian frontier. Washington: Smithsonian Institution Press.

Fisher, W. H. 2003. Name rituals and acts of feeling among the Kayapó (Mebengokré). fournal of the Royal Anthropological Institute 9(1):117-135. DOI: https://doi.org/10.1111/1467-9655.t01-2-00007.

Fortes, M. 2011[1958]. O ciclo de desenvolvimento do grupo doméstico. Brasília: UnB. 
Giannini, I. V. 1991. A ave resgatada: “a impossibilidade da leveza do ser”. Dissertação de Mestrado, Universidade de São Paulo, Departamento de Antropologia Social, São Paulo.

Gordon, C. 2005. Economia selvagem. Ritual e mercadoria entre os índios Xikrin-Mebêngôkre. São Paulo: Edunesp.

Lea, V. 1986. Nomes e Nekrets Kayapó: uma concepção de riqueza. Tese de Doutorado, Universidade Federal do Rio de Janeiro, Museu Nacional, Departamento de Antropologia Social, Campinas.

Lea, V. 1992. Mébengokre (Kayapó) onomastics: a facet of houses as total social facts in Brazil. Man, News Series 27(1):129-153. DOI: https://doi.org/10.2307/2803598.

Lea, V. 1993. Casas e casas Mebengokré (Jê), in Amazônia: etnologia e história indígena. Organizado por E. Viveiros de Castro, e M. C. Cunha. São Paulo: USP-NHII/Fapesp.

Lea, V. 1994. Gênero feminino Mebengokré (Kayapó): desvelando representações desgastadas. Cadernos Pagu (3):85-116.

Lea, V. 1995. Casa-se do outro lado: um modelo simulado da aliança mebengokré (Jê), in Antropologia do parentesco: estudos ameríndios. Organizado por E. Viveiros de Castro, pp. 321-359. Rio de Janeiro: UFRJ.

Lea, V. 1999. Desnaturalizando gênero na sociedade Mebengokré. Estudos Feministas 7(1-2):176-194.

Lea, V. 2005. The great name confirmation ceremonies of the Mẽbengokre of Central Brazil, and the fabrication of beautiful people. Estudios Latinoamericanos 25:87-101.

Lea, V. 2007. Uma aula de choro cerimonial Mẽbêngôkre, in Línguas e culturas Macro-fê. Organizado por A. D. Rodrigues, e A. S. A. C. Cabral, pp. 19-44. Brasília: UnB/Finatec. 
Lea, V. R. 2012. Riquezas intangíveis de pessoas partíveis: os Mẽbêngôkre (Kayapó) do Brasil Central. São Paulo: Edusp e Fapesp.

Lopes da Silva, A. 1986. Nomes e amigos: da prática Xavante a uma reflexão sobre os fê. São Paulo: FFLCH/USP. (Série Antropologia, 6).

Mantovanelli, T. 2016a. Os Xikrin do Bacajá e a Usina Hidrelétrica de Belo Monte: uma crítica indígena à política dos brancos. Tese de Doutorado, Universidade Federal de São Carlos, Departamento de Antropologia Social, São Carlos.

Mantovanelli, T. 2016b. Os Xikrin da Terra Indígena Trincheira-Bacajá e os estudos complementares do rio Bacajá: reflexões sobre a elaboração de um laudo de impacto ambiental. Horizontes Antropológicos 22(46):159-188. DOI: http://dx.doi.org/10.1590/S0104-71832016000200006.

Maybury-Lewis, D. (Org.). 1979. Dialectical Societies: the Gê and Bororo of Central Brazil. Cambridge: Harvard University Press.

Melatti, J. C. 1976. Nominadores e genitores: um aspecto do dualismo krahó, in Leituras de etnologia brasileira. Editado por E. Schaden, pp. 139-148. São Paulo: Companhia Editora Nacional.

Menget, P. 1985. Jalons pour une étude comparative. Journal de la Societé des Americanistes (71):131-141.

Monteiro, E. S. G. (2019). Amijkin é como o vento! Notas etnográficas sobre alegria e festa entre os Krahô. Dissertação de Mestrado, Universidade de São Paulo, Departamento de Antropologia Social, São Paulo.

Ngrenh-djam Xikrin. 2014. O processo de construção de Belo Monte na fala de uma jovem Xikrin, in Belo Monte e a questão indígena. Organizado por J. P. Oliveira, e C. Cohn, pp. 322-325. Brasília: ABA 
Oliveira, J. P., e C. Cohn (orgs.). 2014. Belo Monte e a questão indígena. Brasília: ABA.

Riviere, P. 1984. Individual and Society in Guiana: a comparative study of Amerindian social organization. Cambridge: Cambridge Univerity Press. DOI: https://doi.org/10.1017/CBO9780511558115.

Silva, F. A., e C. Gordon. 2011. Xikrin: uma coleção etnográfica. São Paulo: EDUSP.

Sztutman, R., e C. Cohn. 2003. O visível e o invisível na guerra ameríndia. Sexta-Feira (7):43-56.

Tseouliko, S. 2018a. Entre ciel et terre: socio-spatialité des Mebengôkré-Xikrin. Terre Indigène Trincheira Bacajá (T.I.T.B.) (Pará, Brésil). Tese de Doutorado, École des Hautes Études en Sciences Sociales/Universidade Federal de São Carlos, Departamento de Antropologia Social e Etnologia, Paris/ São Carlos.

Tseouliko, S. 2018b. O mundo dos projetos socioambientais visto pelas mulheres indígenas.Para repensar o ecofeminismo com o caso dos Mẽbêngôkre -Xikrin da Terra Indígena Trincheira Bacajá (TITB, Pará, Brasil). Campos 19(1):87-112.

Turner, T. 1966. Social structure and political organization among the Northern Kayapo. PHD Dissertation, Harvard University, Department of Social Relations, Cambridge.

Turner, T. 1979a. The Gê and Bororo societies as dialectical systems: a general model, in Dialectical Societies: the Gê and Bororo of Central Brazil. Organizado por D. Maybury-Lewis, pp. 145-178. Cambridge: Harvard University Press.

Turner, T. 1979b. Kinship, household, and community structure among the Kayapó, in Dialectical Societies: the Gê and Bororo of Central Brazil. Organizado por D. Maybury-Lewis. Cambridge, Harvard University Press. 
Verswijver, G. 1992. The club-fighters of the Amazon. Warfare among the Kayapo Indians of Central Brazil. Gent: Rijksuniversiteit te Gent.

Viveiros de Castro, E. 2002. A inconstância da alma selvagem e outros ensaios de antropologia. São Paulo: Cosac\&Naifi.

Vidal, L. B. 1977. Morte e vida de uma sociedade indígena brasileira. São Paulo, Hucitec.

Vidal, L. B. 1992. A pintura corporal e a arte gráfica entre os Kayapó-Xikrin do Cateté, in Grafismo indígena. São Paulo: Nobel/EDUSP/FAPESP. 